\title{
Performance Evaluation of Pyrolysis Cookstove Using Water Boiling Test
}

\author{
Teka Tesfaye Mengesha ${ }^{1}$, Ancha Venkata Ramayya ${ }^{2}$ \\ ${ }^{1}$ Rural Energy Engineering Case Team, Jimma Agricultural Engineering Research Center, Oromia Agricultural Research Institute, Jimma, \\ Ethiopia \\ ${ }^{2}$ Department of Mechanical Engineering, Jimma University Institute of Technology, Jimma, Ethiopia
}

Email address:

tekamen@yahoo.com (T. T. Mengesha), Venkata9999@yahoo.com (A. V. Ramayya)

\section{To cite this article:}

Teka Tesfaye Mengesha, Ancha Venkata Ramayya. Performance Evaluation of Pyrolysis Cookstove Using Water Boiling Test. American Journal of Modern Physics. Vol. 6, No. 5, 2017, pp. 108-116. doi: 10.11648/j.ajmp.20170605.15

Received: March 20, 2017; Accepted: April 19, 2017; Published: September 12, 2017

\begin{abstract}
For domestic energy - fuel sources biomass such as wood, animal dung and agricultural waste that are normally burned in traditional stove is used by the developing world. Diverse biomass resource is found in Ethiopia which can be used for energy through pyrolysis cook stove co-producing biochar. Specifically, coffee husks are the major solid residues from the handling and processing of coffee in the study area. The purpose of this study is to evaluate these Biochar producing pyrolysis cooking stove with respect to energy and emission. The selection of the stove design was made from both allothermal and autothermal type of pyrolysis cook stove. Both with and without biomass insertion was the experiment done for the allothermal stove design to understand the effect of the pyrolysis gas. The Water boiling test was used for the selected indirect and direct type stove design using wood and Corn cob respectively as fuel for testing stove efficiency. Both coffee husk and corncob as a biomass resource was used for generating pyrolysis gas and biochar using the selected indirect stove design. HOBO Carbon Monoxide Data logger and University of California Berkeley Particle Monitor device was used for measuring Carbon Monoxide and Particle Matter. The results from the water boiling test suggest that the indirect type stoves, without biomass insertion, average thermal efficiency was found between 15.86 to $18.6 \%$ during high power test and $20.02 \%$ average thermal efficiency was found for clay made stove during low power test. With biomass insertion corn cob and coffee husk the maximum average thermal efficiency is obtained during low power test using clay made stove $23.78 \%$ and $24.19 \%$ respectively. For direct type stoves the maximum and minimum thermal efficiency was found $34.11 \%$ for clay made stove and $20.4 \%$ for ELSA stove respectively during high power hot start phase.
\end{abstract}

Keywords: Stove, Efficiency, Energy, Biomass, Wood

\section{Introduction}

Energy consumption in the developed and developing worlds is greatly different. Currently, the developed world predominantly consumes energy produced from fossil fuels, and to some extent, renewable energy sources. In contrast, the developing world still largely dependent on biomass such as wood, dung and agricultural waste for domestic energy - fuel sources that are typically burned in traditional stoves. Half of the world population depend on biomass fuels for energy [1].

Earlier the motivation for stove design development was to increase efficiency and reduction of emissions [2]. Due to greenhouse gases problem the transition to new stove technologies accelerated which can produce both heats and bio char for cooking, soil building and carbon sequestration [3].

In the past Improved cook stoves have been developed that can address the issues of decreasing fuel wood supply. Pyrolysis of Biomass gives the possibility to increase the feedstock options, and utilize different residues to supplement woody biomass.

These Biochar-producing stoves are yet an immature technology, and in fact, the emissions, energy and their climate change mitigation potential from the few designs that have been developed have not yet been systematically tested [4]. A modified Top-lit updraft gasifier stove has been produced, tested and compared with a traditional three-stone fire. The results indicate that variations in geometry of the 
Top-lit updraft gasifier are essential to ensure improved combustion [5].

The introduction of a pyrolysis stove to a smallholder farming system, similar to other improved cook stoves, may increase energy efficiency [6]. Biochar producing pyrolysis stove operations has two basic categories. Auto thermal pyrolysis stove type produces Biochar by direct burning of the biomass. The Allothermal pyrolysis stove type involves burning the biomass for fuel in the inner chamber and biomass to be charred in the annular portion of an outer chamber. Heat transfer occurs from the burning fuel in the inner chamber to the biomass to be charred in the outer chamber.

Ethiopia produces considerable amount of biomass each year which has been utilized for domestic energy purpose, mainly by direct combustion. On the contrary, coffee husk from coffee processing industries is not used as a fuel in most cases due to the poor handling of coffee husk to be used as domestic fuel with the current technology.

Coffee production capacity of the country, which was estimated at 301,000 tons during 2006, is targeted to increase to 419,000 tons by the end of $2010[7,8]$. The total area of coffee is about 400,000 ha with a total production of 200,000 tons of clean coffee per anum. This yield is associated with an estimated amount of 242,000 tons of by-product as coffee residue (coffee husk and pulp) [9]. Coffee husks are the major solid residues from the handling and processing of coffee, since for every $\mathrm{kg}$ of coffee beans produced, approximately $1 \mathrm{~kg}$ of husks are generated.

Prosopis is a wild tree (shrub) that grows across hundreds of hectares of the Afar and Somali regions. They use the prosopis wood as fuel wood and for fence and house construction. Since it has formed thick forest, the Afars have continuously appealed for the eradication of gardens and people. The economic and social benefits of using prosopis wood or branches as a fuel energy for industry are quite evident [10].

The northeastern and southeastern lowlands of the country are being invaded by Prosopisjuliflora (hereafter Prosopis) at an alarming rate. The species is forming monospecific thickets, and roads, watering areas, farms and grazing areas are being lost. The species is now pantropically introduced and is spreading, often as a weed currently invading areas in the Afar and Somali Regional States [11].

The total number of saw mills in Ethiopia is approximately 39 , with a total of 5-10 factories involved in the production of plywood. A total of $200-300$ joinery and furniture factories also operate in different parts of the country. Most of the saw mills are located in the southern and south-western parts of the country. Sawmill residue is estimated to total about 25,000 tonnes per year. Residues generated in sawmills located in remote areas of the country have insignificant economic value and are usually dumped or piled up and allowed to rot.

At TiroBotorBetcho and Ethio Plywood Enterprise (Jimma), the off-cuts and slabs are used for firing the boilers, while saw dust is disposed of into the river or piled up in fields; at the Ethio Plywood Enterprise in Jimma, the saw dust is freely given to workers. Some of the sawmills located in remote areas (away from large towns) might nonetheless be of interest as these mills have already piled up a considerable amount of residue for lack of alternative uses [10].

Maize is one of the most important cereals cultivated in Ethiopia. It ranks second after teff in area coverage and first in total production. The results of the year 2011/12, Meher season post-harvest crop production survey indicate that total land areas of about 12,086,603.89 hectares were covered by grain crops. Out of the total grain crop areas, $79.34 \%$ $(9,588,923.71$ hectares) was under cereals. Of this maize covered 17\% (about 2,054,723.69 hectares) and gave 6069413 tonnes of grain yields [12]. Since corn cob is the solid residues from maize, it is a good resource potential for the biochar production.

So driven by massive population growth and rural poverty, biomass is expected to source significant share world energy requirement [13]. With the aid of appropriate technology design biomass resources can provide renewable energy and biochar. Therefore, the objective of this study was to evaluate these Biochar producing pyrolysis cooking stove with respect to energy and emission.

\section{Experimental Setup}

\subsection{Location}

Jimma, is the largest city in southwestern Ethiopia. It is a special zone of the Oromia Region and is surrounded by Jimma Zone. It has a latitude and longitude of $7^{\circ} 40^{\prime} \mathrm{N} 36^{\circ} 50^{\prime} \mathrm{E}$.

The research was conducted at both Jimma University, Jimma Institute of Technology and Jimma Agricultural Engineering Research Center.

\subsection{Stove Design Selection and Description}

The selection of the stove design from both Allothermal and auto-thermal was based on local availability of material, less complex manufacturing and operation methods and batch or continuous feeding of fuel.
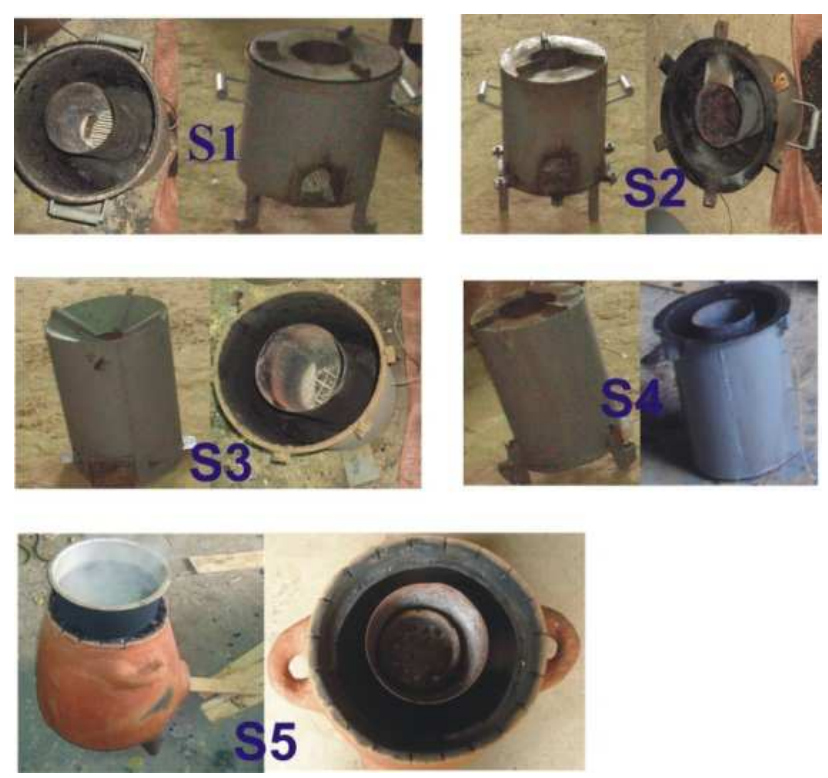

Figure 1. Allothermal stove type. 

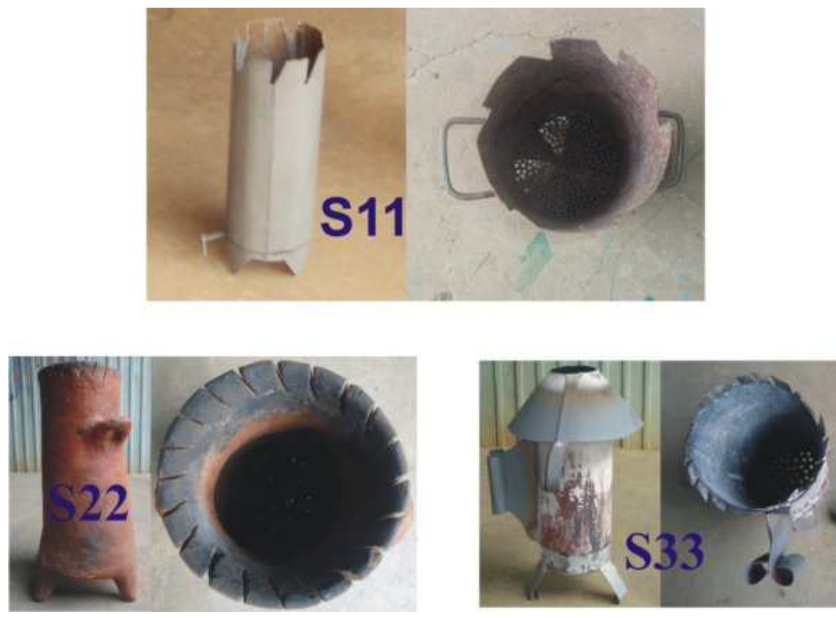

Figure 2. Auto thermal stoves.

Anila Stove (S4) - The Anila stove is a simple technology for converting biomass to char at household level. The Stove has been designed and built by Professor U.N. Ravikumar of the Mysore University in India. The stove consists of two metal barrels. The outer barrel is filled up with biomass and the inner with firewood. After burning the fuel wood for 3040 minutes, the pyrolysis of the biomass starts.

Cornel Design Stove (S3) - This stove design was taken from Cornell University. The stove has an outer shell for secondary air and pot rest, pyrolysis chamber with legs and pyrolysis chamber lid for protecting syngas leakage.

ELSA Stove (S33) - ELSA is a small burner designed for the studying of the micro-gasification process. The microgasification inside Elsa is a self-sustaining process and doesn't require any auxiliary energy. ELSA is made from stainless steel flat parts and is assembled without any screws or welds, just by folding the different parts.

Continuous feeding Anila Stove (S2) - Anila stove was modified to make the fuel (wood) Continuous, Reduced height and increased outer diameter with flange tightened at six place using bolt and nut.

Continuous feed flange less Anila stove (S1) - It is similar to the above Anila continuous but there is no flange and the lid simply put at the top and the vessel rest on the lid.

Panwar 2009 direct type stove (S11) - The biomass stove was designed and fabricated to meet the cooking energy requirement of a family having 4-6 persons. The stove consists of cylindrical reactor, cast iron grate and adjustable air opening from bottom end. The reactor is a mild steel cylinder having diameter about $16 \mathrm{~cm}$ and height about $47 \mathrm{~cm}$.

Clay made Continuous feeding Anila flange less stove (S5) It is similar to continuous feeding Anila flange less stove but the difference is only manufacturing material which is Clay.

Clay made Panwar 2009 direct type stove(S22)- It is similar to Panwar 2009 direct type stove but the difference is only material.

\subsection{Water Boiling Test}

For each of the three testing phases, water boiling test version 4.2.2 (Released 22 April 2013) was used which involves a series of measurements and calculations.

The fuel consumed (moist) is the mass of wood used to bring the water to a boil, found by taking the difference of the pre-weighed bundle of wood and the wood remaining at the end of the test phase:

$$
\mathrm{f}_{\mathrm{cm}}=\mathrm{f}_{\mathrm{ci}}-\mathrm{f}_{\mathrm{cf}}
$$

Where $f_{c i}$ Mass of fuel before test in grams,

\section{$\mathrm{f}_{\mathrm{cf}}$ Mass of fuel after test in grams}

The net change in char during the test is the mass of char created during the test, found by removing the char from the stove at the end of the test phase. Because it is very hot, the char will be placed in an empty pre-weighed container of mass $k$ and weighing the char with the container, then subtracting the container mass from the total:

$$
\Delta \mathrm{c}_{\mathrm{c}}=\mathrm{c}_{\mathrm{c}}-\mathrm{k}
$$

Where $c_{c}$ Mass of char with dish after test in grams

The mass of water vaporized is a measure of the water lost through evaporation during the test. It is calculated by subtracting the initial weight of pot and water minus final weight of pot and water.

$$
\mathrm{w}_{\mathrm{cV}}=\mathrm{p} 1_{\mathrm{ci}}-\mathrm{p} 1_{\mathrm{cf}}
$$

Where $\mathrm{p} 1_{\mathrm{ci}}$ Mass of pot of water before test in grams $\mathrm{p} 1_{\mathrm{cf}}$ Mass of pot of water after test in grams

The effective mass of water boiled is the water remaining at end of the test. It is a measure of the amount of water heated to boiling. It is calculated by simple subtraction of final weight of pot and water minus the weight of the pot.

$$
\mathrm{w}_{\mathrm{cr}}=\mathrm{p} 1_{\mathrm{cf}}-\mathrm{p} 1
$$

Where p1 dry mass of empty pot in grams

The time to boil pot1 is the difference between start and finish times:

$$
\Delta \mathrm{t}_{\mathrm{c}}=\mathrm{t}_{\mathrm{cf}}-\mathrm{t}_{\mathrm{ci}}
$$

Where $t_{c i}$ Time at start of test in min,

$\mathrm{t}_{\mathrm{cf}}$ Time at end of test in min

The equivalent dry fuel consumed $\left(\mathrm{f}_{\mathrm{cd}}\right)$ adjusts the amount of dry fuel that was burned in order to account for two factors: (1) the energy that was needed to remove the moisture in the fuel and (2) the amount of char remaining unburned. The mass of dry fuel consumed is the moist fuel consumed minus the mass of water in the fuel:

$$
\text { dry fuel }=f_{c m} *(1-m c)
$$

Where $m_{c}$ moisture content ( $\%$-wet basis)

The energy that was needed to remove the moisture in the fuel $\left(\Delta \mathrm{E}_{\mathrm{H}_{2} \mathrm{O}, \mathrm{c}}\right)$ is the mass of water in the fuel multiplied by 
the change in specific enthalpy of water.

$$
\Delta \mathrm{E}_{\mathrm{H}_{2} \mathrm{O}, \mathrm{c}}=\mathrm{f}_{\mathrm{cm}} * \mathrm{mc}^{*}\left(4.186 *\left(\mathrm{~T}_{\mathrm{b}}-\mathrm{T}_{\mathrm{a}}\right)+2257\right)
$$

Where $\mathrm{T}_{\mathrm{a}}$ Ambient Temperature $\left({ }^{\circ} \mathrm{C}\right)$,

$\mathrm{T}_{\mathrm{b}}$ Local boiling point of water $\left({ }^{\circ} \mathrm{C}\right)$,

This quantity of energy is divided by the energy content of the fuel to determine the equivalent mass of fuel required to remove the moisture in the fuel:

Where LHV Net calorific value, in $\mathrm{kJ} / \mathrm{kg}$

$$
\text { fuel to evaporate water }=\frac{\Delta \mathrm{E}_{\mathrm{H}_{2} \mathrm{O}, \mathrm{c}}}{\mathrm{LHV}}
$$

The fuel energy stored in the char remaining

$$
\Delta \mathrm{E}_{\text {char,c }}
$$

is the mass of char multiplied by the energy content of the char:

$$
\Delta \mathrm{E}_{\text {char }, \mathrm{c}}=\Delta \mathrm{c}_{\mathrm{c}} * \mathrm{LHV}_{\text {char }}
$$

This quantity of energy is divided by the energy content of the fuel to determine the equivalent amount of unburned fuel remaining in the form of char:

$$
\text { fuel in char }=\frac{\Delta \mathrm{E}_{\text {char,c }}}{\text { LHV }}
$$

Putting it all together we have:

$$
\mathrm{f}_{\mathrm{cd}}=\text { dry fuel-fuel to evaporate water-fuel in char }
$$

Thermal efficiency: This is a ratio of the work done by heating and evaporating water to the energy consumed by burning fuel. It is an estimate of the total energy produced by the fire that is used to heat the water in the pot. It is calculated in the following way:

$$
\mathrm{h}_{\mathrm{c}}=\frac{4.186 *\left(\mathrm{~T}_{\mathrm{cf}}-\mathrm{T} 1_{\mathrm{ci}}\right) *\left(\mathrm{p} 1_{\mathrm{ci}}-\mathrm{p} 1\right)+2260 * \mathrm{w}_{\mathrm{cv}}}{\mathrm{f}_{\mathrm{cd}} * \mathrm{LHV}}
$$

Burning rate: This is a measure of the rate of fuel consumption while bringing water to a boil. It is calculated by dividing the equivalent dry fuel consumed by the time of the test.

$$
r_{c b}=\frac{f_{c d}}{\Delta t_{c}}
$$

Firepower: This is the fuel energy consumed to boil the water divided by the time to boil. It tells the average power output of the stove (in Watts) during the high-power test:

$$
\mathrm{FP}_{\mathrm{c}}=\frac{\mathrm{f}_{\mathrm{cd}}{ }^{*} \mathrm{LHV}}{\Delta \mathrm{t}_{\mathrm{c}} * 60}
$$

The moisture content of the fuel, wood and Corncob was measured using Standard test method for direct moisture content measurement of wood and wood-Base materials D4442-92(Reapproved 2003).

Dulong's formula for calculating the calorific value is given as[14]:

$$
\left.\mathrm{HHV}=\frac{1}{100} *\left[35000 \mathrm{C}+143000 *\left(\mathrm{H}-\frac{\mathrm{O}}{8}\right)+9160 \mathrm{~S}\right)\right] \frac{\mathrm{kJ}}{\mathrm{kg}}
$$

Higher calorific value from the higher values of the ultimate analysis of wood:

$$
\left.\mathrm{HHV}=\frac{1}{100} *\left[35000 *(53)+143000 *\left(7-\frac{44}{8}\right)+9160 * 0.1\right)\right] \frac{\mathrm{kJ}}{\mathrm{kg}}
$$

$\mathrm{HHV}=20704 \mathrm{~kJ} / \mathrm{kg}$

$$
\mathrm{LHV}=\left[\mathrm{HHV}-\frac{9 \mathrm{H}}{100} * 2442\right] \frac{\mathrm{kJ}}{\mathrm{kg}}
$$

Table 1. Ultimate analysis of wood, Corn cob and Corn cobBiochar.

\begin{tabular}{lllll}
\hline $\begin{array}{l}\text { Ultimate } \\
\text { analysis }\end{array}$ & $\begin{array}{l}\text { Lower } \\
\text { (wood) }\end{array}$ & $\begin{array}{l}\text { Higher } \\
\text { (wood) }\end{array}$ & $\begin{array}{l}\text { Corn } \\
\text { cob }\end{array}$ & $\begin{array}{l}\text { Corn cob } \\
\text { Biochar }\end{array}$ \\
\hline $\mathrm{C}$ & 50 & 53 & 47.35 & 77.6 \\
$\mathrm{H}$ & 5.8 & 7 & 5.9 & 3.05 \\
$\mathrm{~N}$ & 0 & 0.34 & 0.69 & 0.85 \\
$\mathrm{Cl}$ & 0.0001 & 0.1 & 0 & 0 \\
$\mathrm{O}$ & 38 & 44.0 & 38.07 & 5.11 \\
$\mathrm{~S}$ & 0 & 0.1 & 0.18 & 0.02 \\
Ash & 0.1 & 2.0 & 1.94 & 13.34 \\
\hline
\end{tabular}

Source $[14,15]$

The lower calorific value $\mathrm{LHV}=19165.7 \mathrm{~kJ} / \mathrm{kg}$ obtained from the higher value of the ultimate analysis of the wood. The LHV of the wood char is $30,000 \mathrm{~kJ} / \mathrm{kg}$ [16].

Corn cob has $H H V=17800 \mathrm{~kJ} / \mathrm{kg}$ and $\mathrm{LHV}=16924 \mathrm{~kJ} / \mathrm{kg}$. But Corn cob char has HHV $=30000 \mathrm{~kJ} / \mathrm{kg}$.

Moisture content of both the fuel was determined using Drying oven.

The wood moisture content on a wet basis, defined by the following formula

$$
\mathrm{mc}=\frac{\mathrm{m}_{\text {fuel,wet }}-\mathrm{m}_{\text {fuel,dry }}}{\mathrm{m}_{\text {fuel,wet }}}
$$

The effective calorific value of the fuel takes account of the energy required to heat and evaporate the moisture present in the fuel

$$
\mathrm{EHV}=\mathrm{LHV}^{*}\left(1-\mathrm{mc}_{\text {wet }}\right)-\mathrm{mc}_{\text {wet }}{ }^{*} \Delta \mathrm{h}_{\mathrm{H}_{2} \mathrm{O}}
$$

$$
\mathrm{EHV}=\mathrm{LHV} *\left(1-\mathrm{mc}_{\mathrm{wet}}\right)-\mathrm{mc}_{\mathrm{wet}} *\left(\left(\mathrm{~T}_{\mathrm{b}}-\mathrm{T}_{\text {fuel, } \mathrm{i}}\right) * 4.2+2260\right)
$$

where

$\mathrm{T}_{\mathrm{b}}=\left(100-\frac{\mathrm{h}}{300}\right)$ is the local boiling point of water in degree centigrade

$\mathrm{T}_{\text {fuel,i }}$ is the initial temperature 
$\mathrm{h}$ is altitude in meter, Jimma $1763 \mathrm{~m}$ [17]

For indirect stove, biomass for char production is not inserted during water boiling test.

\subsection{Emission Testing}

Carbon Monoxide and Particulate Matter were chosen as Indoor Air Pollutants to be measured since they have most consistently been associated with respiratory and cardiovascular health effects. The Carbon Monoxide concentrations in the cooking rooms were measured with the HOBO Carbon Monoxide logger, which was set to record concentration every minute.

Fine particulate matters were measured by the University of California Berkeley Particle Monitor, which uses a photoelectric detector. The UCB PM measured the Particulate Matter concentration every minute (reported in units of milligrams Particulate Matter per cubic meter of air, $M g / M^{3}$.

\section{Results and Discussions}

\subsection{Allothermal Stove Without Biomass}

Figure 3 shows the average thermal efficiency of the indirect heating type stove designs. when we compare between the selected stove designs the thermal efficiency was found $15.86 \%$ to $20.02 \%$ for high power cold start except S3 stove design which is below $15 \%$. The thermal efficiency of clay made stove (S5) is higher for low power phase water boiling test than high power test as expected.

But the thermal efficiency of 3-stone open fire is $9.50 \%$ for high power cold start, $9.20 \%$ for high power hot start and $30.00 \%$ for low power phase [18]. For that of traditional metal stove using charcoal as fuel material is $11 \%$ [19]. The average thermal efficiency of open top gasifier was found to be $19.26 \%$ which is greater than the traditional biomass cooking system [20].

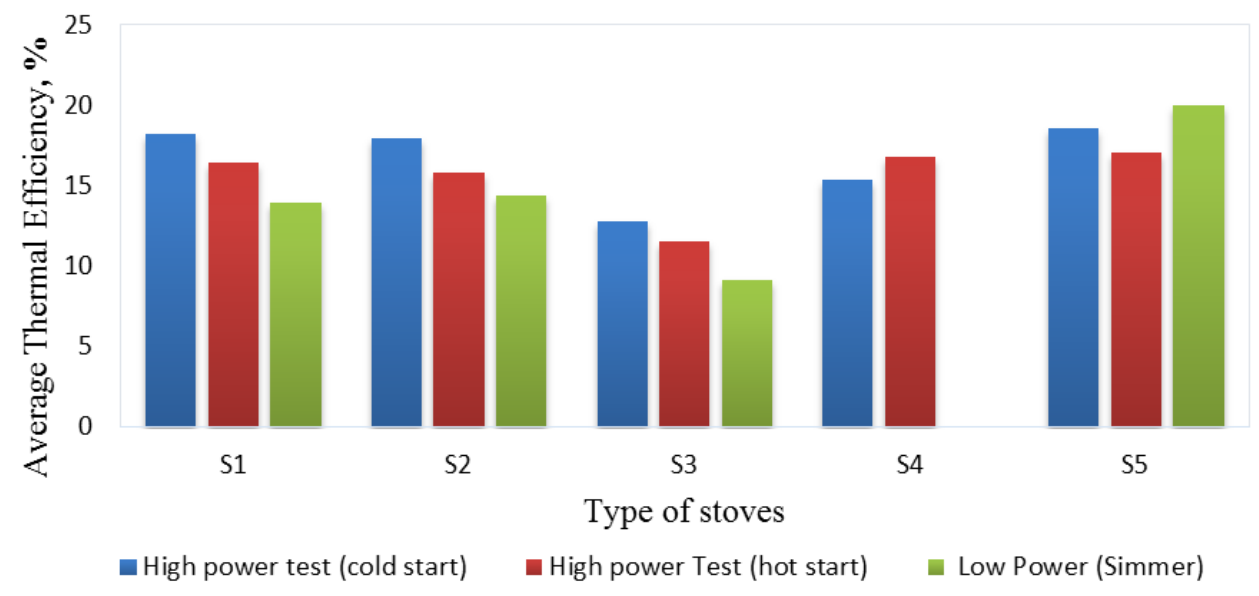

Source: Experimental data

Figure 3. Average Thermal efficiency of indirect type stove without Biomass.

Figure 4 shows that the firepower (i.e. the ratio of the wood energy consumed by the stove per unit time). In this aspect of stove performance also the S3 and S4 has high average Fire power indicating greater wood consumption over a longer duration.

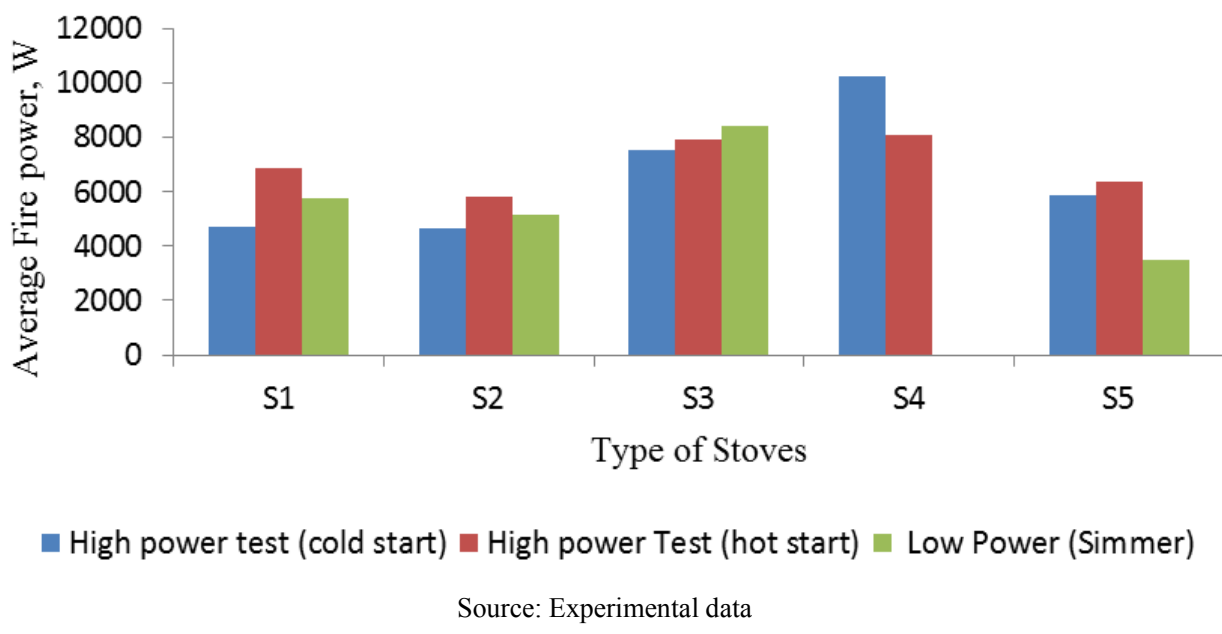

Figure 4. Average Fire Power of indirect type stove without Biomass. 
Figure 5 indicate the Turndown ratio of the stoves which is also known as control efficiency, determined by noting the difference in fuel consumption per minute between high power (bringing water to a boil or frying) and low power (simmering). Stoves with a higher turn down ratio are likely to use less fuel during a real cooking task, which involves bringing food to a boil and then cooking it at a simmer for an extended period of time. Clay made stove (S5)has better turndown ratio.

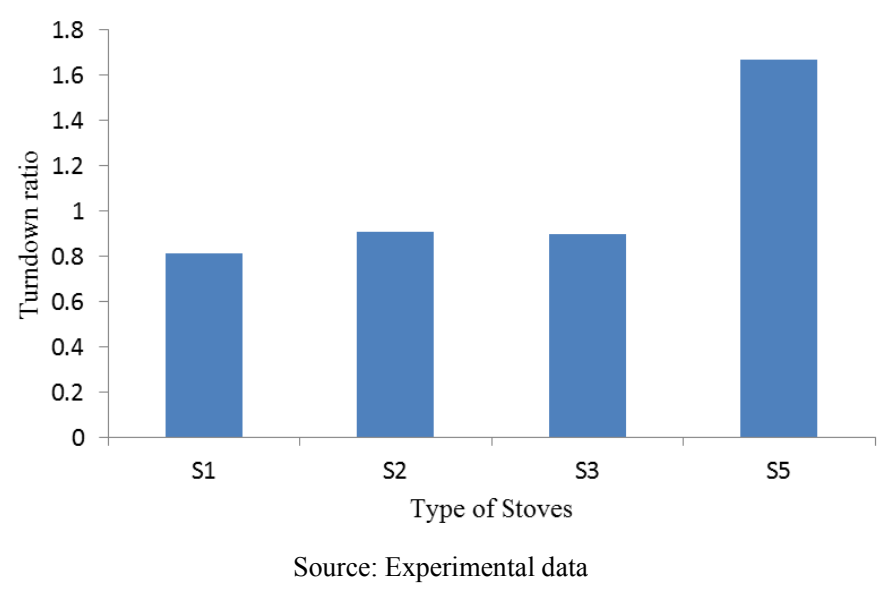

Figure 5. Average Turndown Ratio of indirect type stove without Biomass.

\subsection{Allothermal Stove with Biomass}

From the result, the effect of biomass was seen during the tests. More volatile gas was produced during high power test for coffee husk than corn cob biomass showing differences between the feedstock due to the void fraction and the particle density. The volatile gas production is faster for coffee husk than corncob biomass. In the Low power phase the difference between the feedstock is not observed [21]. The production of the pyrolysis gas increases the thermal energy efficiency by decreasing the fuel consumption for cooking purpose.

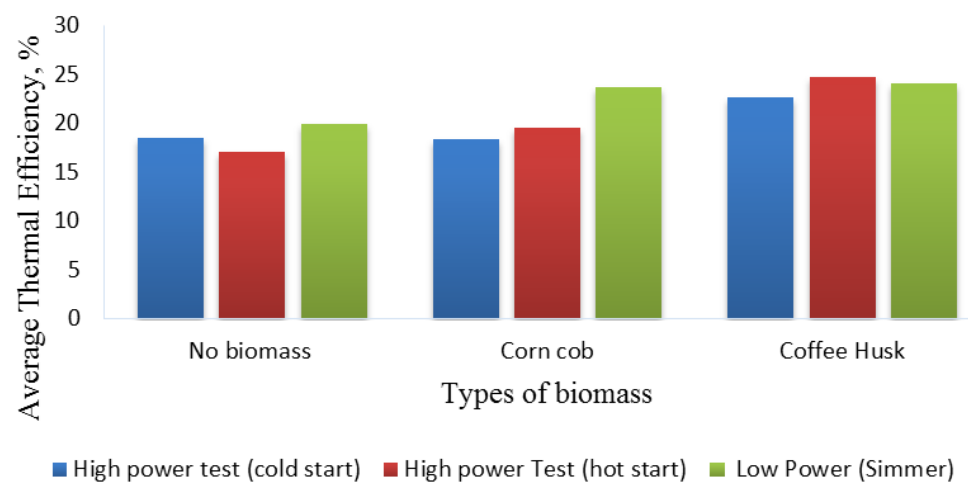

Source: Experimental data

Figure 6. Average Thermal efficiency of indirect type stove with Biomass.

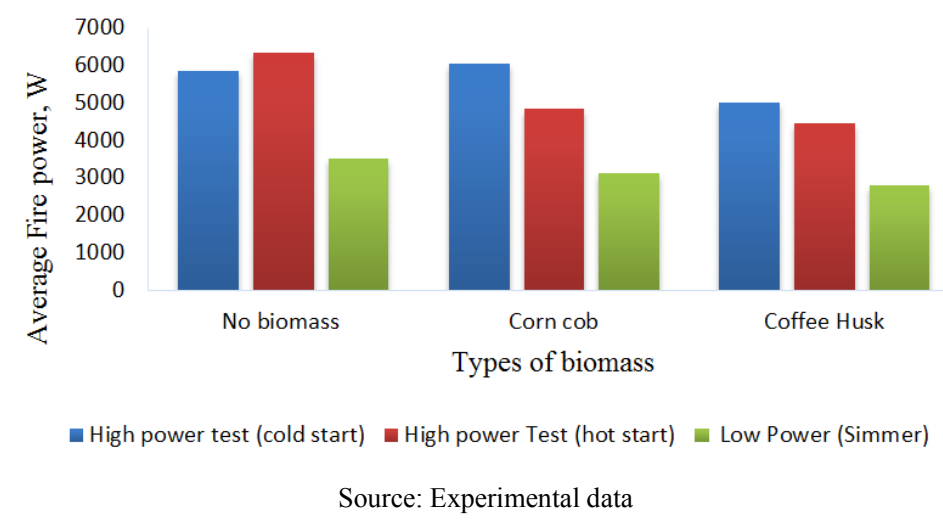

Figure 7. Average Fire Power of indirect type stove with Biomass. 


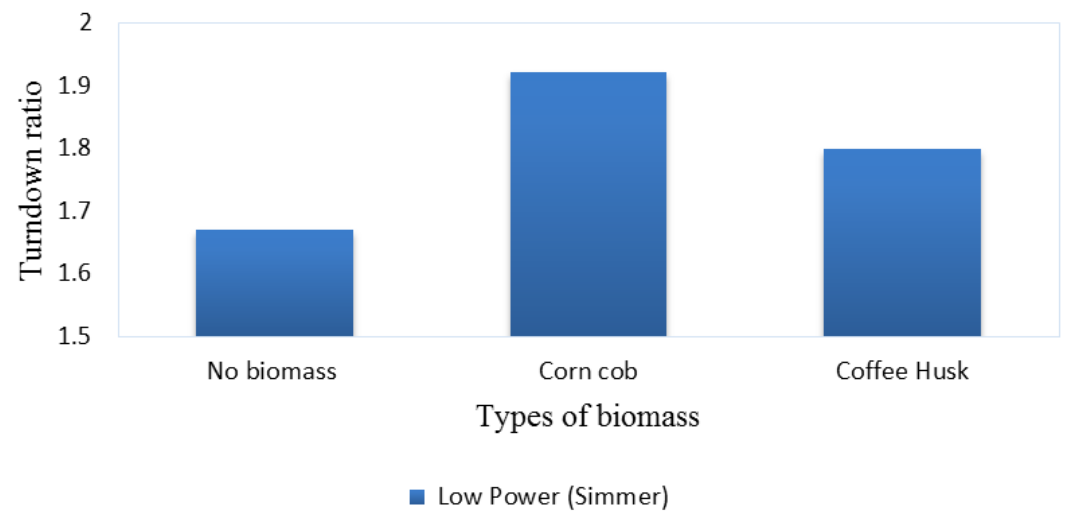

Source: Experimental data

Figure 8. Average Turndown Ratio of indirect type stove with Biomass.

\subsection{Auto-thermal Stove}

In the following figure 9 and 10 we can see the average thermal efficiency and average Fire power of the direct type stove designs. The thermal efficiency of clay made (S22) is better ( 29 to $34.11 \%$ ) than others especially during high power hot start phase.

This [22] says the same stove design with insulation was tested for Babul wood (Prosopis julliflora) and Groundnut (Arachis hypogaea) shell briquette yielding thermal efficiency of 34.8 and $35.2 \%$ respectively.

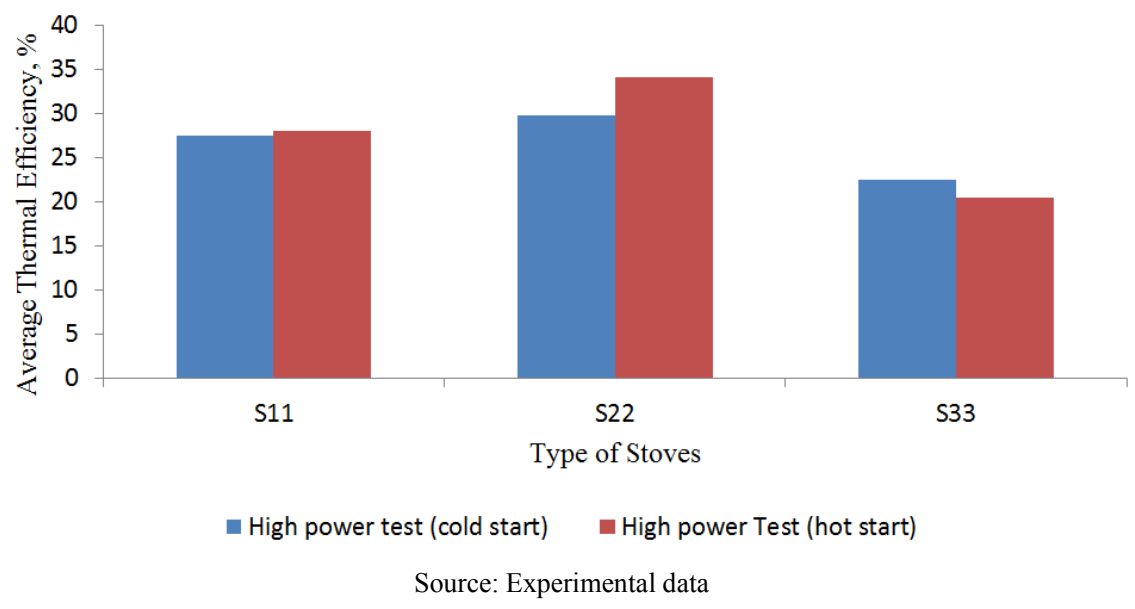

Figure 9. Average Thermal efficiency of direct type stove.

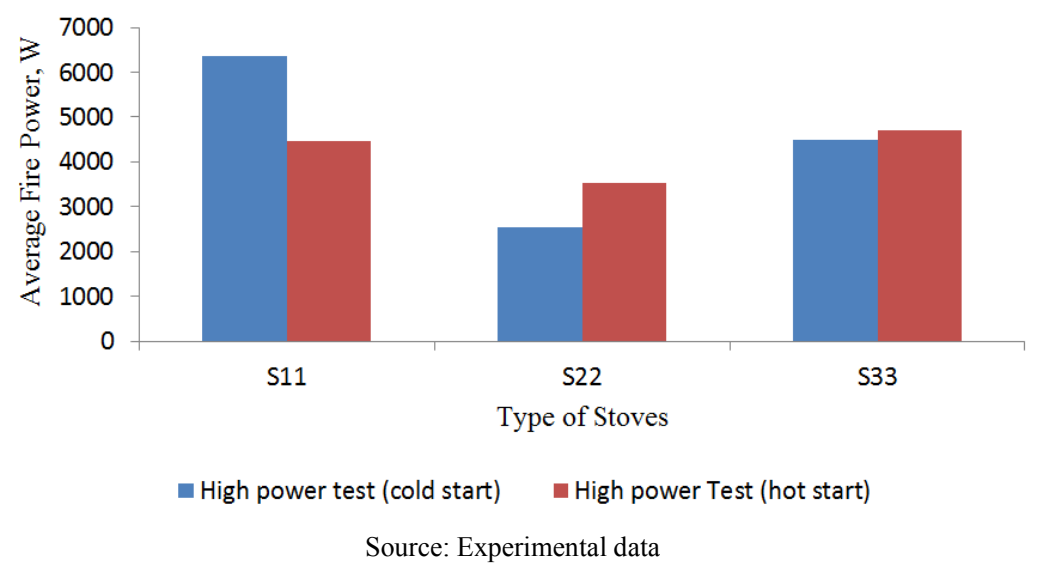

Figure 10. Average Fire Power of direct type stove.

\subsection{Emission Test}

Figures 11 and 12 shows the test result of Carbon monoxide and particulate matter from the stoves. 


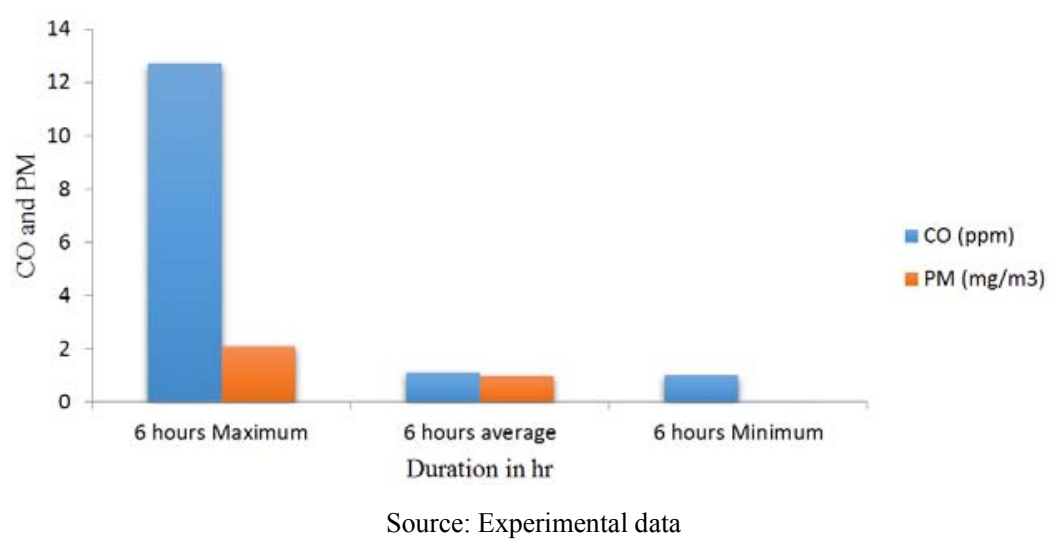

Figure 11. PM and CO test result of the stoves.

Using the traditional open fire (fogon), AVerage $\mathrm{PM}_{2.5}$ 24-h personal exposure was $0.29 \mathrm{mg} / \mathrm{m}^{3}$ and mean $48-\mathrm{h}$ kitchen concentration was $1.269 \mathrm{mg} / \mathrm{m}^{3}$ [23]. The CO standards for residential area are $2 \mathrm{mg} / \mathrm{m}^{3}$ of 8 -h average in India [24]. The average personal CO exposure during daily cooking was $7.4 \mathrm{ppm}$, with a range between 0.82 and 18.5 ppm [25]. 24-hr concentrations for $\mathrm{CO}$ and $\mathrm{PM}_{2.5}$ were $2.5 \mathrm{mg} / \mathrm{m}^{3}$ and $1.8 \mathrm{mg} / \mathrm{m}^{3}$, respectively, for the unimproved mud stove kitchens and were $2.0 \mathrm{mg} / \mathrm{m}^{3}$ and $0.73 \mathrm{mg} / \mathrm{m}^{3}$, respectively, for the BCSIR improved stove kitchens [26]. The highest indoor concentrations of $\mathrm{PM}_{2.5}$ were observed in homes using the open fire ( avg. $=5.31 \mathrm{mg} / \mathrm{m}^{3}$ ) or equivalent, although homes using the plancha — indigenous wood-burning stove with chimney — also had measurements $>13.8 \mathrm{mg} / \mathrm{m}^{3}, \mathrm{PM}_{2.5}$ limit of detection. The highest indoor concentrations of $\mathrm{CO}$ were also observed in homes using the open fire $($ avg. $=22.9 \mathrm{ppm})$, with a maximum measurement of $>250 \mathrm{ppm}$ [27].

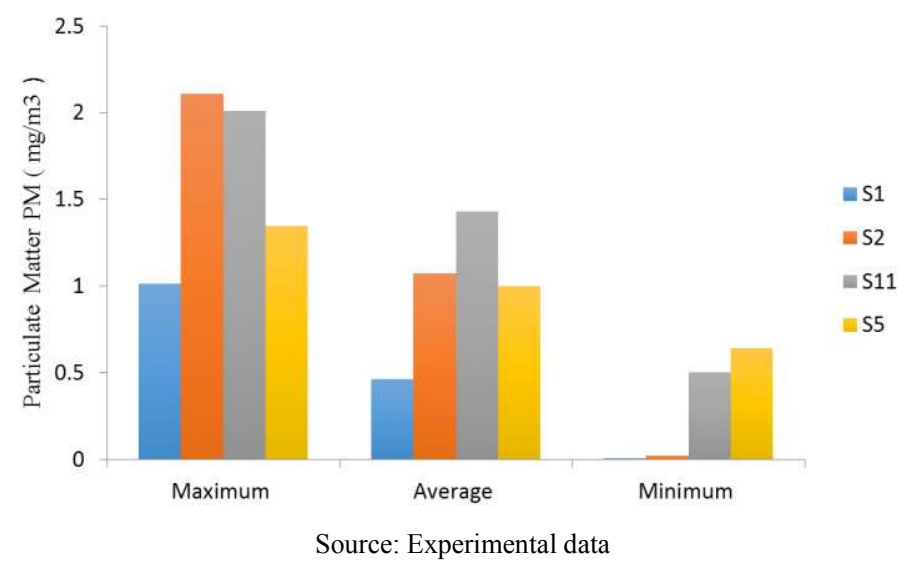

Figure 12. PM test result of the stoves.

\section{Conclusion}

The results from the water boiling test suggest that the indirect type stoves, without biomass insertion, average thermal efficiency was found between 15.86 to $18.6 \%$ during high power test and $20.02 \%$ average thermal efficiency was found for clay made stove during low power test. With biomass insertion corn cob and coffee husk the maximum average thermal efficiency is obtained during low power test using clay made stove $23.78 \%$ and $24.19 \%$ respectively. For direct type stoves the maximum and minimum thermal efficiency was found $34.11 \%$ for clay made stove and $20.4 \%$ for ELSA stove respectively during high power hot start phase. The maximum and minimum $\mathrm{CO}$ and PM concentration was
12.7 and $1 \mathrm{ppm}$ and 2.11 and $0.01 \mathrm{gm} / \mathrm{m}^{3}$ respectively. Definitely from this experimental test it can be concluded that, the stove geometry, air inlet and fuel inlet configuration has high impact in increasing the efficiency of the stove.

\section{References}

[1] WHO. Household air pollution and health [Internet]. 2014. Available from: http://www.who.int/mediacentre/factsheets/fs292/en/

[2] Kishore VV. Thermochemical Conversion of biomass. Renewable Energy Engineering and Technology: Principles and Practice. TERI press; 2010. p. 697. 
[3] IBI. BIOCHAR STOVES [Internet]. 2014. Available from: http://www.biochar-international.org/technology/stoves

[4] Whitman T, Nicholson CF, Torres D, Lehmann J. Climate change impact of biochar cook stoves in western Kenyan farm households: System dynamics model analysis. Environ. Sci. Technol. [Internet]. 2011;45(8):3687-3694. Available from: http://www.ncbi.nlm.nih.gov/pubmed/21446727

[5] Birzer C, Medwell P, Wilkey J, West T, Higgins $M$, Macfarlane G, et al. An analysis of combustion from a top-lit up-draft (TLUD ) cookstove. Humanitarian Engineering. $2009 ; 2(1): 1-8$.

[6] Torres-Rojas D, Lehmann J, Hobbs P, Joseph S, Neufeldt H. Biomass availability, energy consumption and biochar production in rural households of Western Kenya. Biomass and Bioenergy [Internet]. Elsevier Ltd; 2011;35(8):35373546. Available from: http://linkinghub.elsevier.com/retrieve/pii/S096195341100258 3

[7] Finance M of, (MoFED) ED. Ethiopia: Building on Progress A Plan for Accelerated and Sustained Development to End Poverty; Ministry of Finance and Economic Development [Internet]. 2014. Available from:

http://www.afdb.org/fileadmin/uploads/afdb/Documents/PolicyDocuments/Plan_for_Accelerated_and_Sustained_(PASDEP) _final_July_2007__Volume_I_3.pdf

[8] Kassa H, Suliman H, Workayew T. Evaluation of Composting Process and Quality of Compost from Coffee By-Products (Coffee Husk and Pulp). Environmental Studies and Management. 2011;4(4).

[9] Kassa H, Workayehu T. Evaluation of some additives on coffee residue (coffee husk and pulp ) quality as compost, southern Ethiopia. Agricultural and Soil Science. 2014;2(2):14-21.

[10] Seboka Y, Getahun MA, Haile-meskel Y. United Nations Development Programme Biomass Energy for Cement Production: Opportunities in Ethiopia [Internet]. 2009. Available from: http://www.environmentportal.in/files/Biomass energy for cement production.pdf

[11] Berhanu A, Tesfaye G. The Prosopis Dilemma, Impacts On Dryland Biodiversity and Some Controlling Methods. The Drylands. 2006;1(2):158-164.

[12] AGENCY CS. The Federal Democratic Republic of Ethiopia Central Statistical Agency Agricultural Sample Survey Report On : Area and Production of Major Crops. 2013.

[13] Guta DD. Assessment of Biomass Fuel Resource Potential And Utilization in Ethiopia: Sourcing Strategies for Renewable Energies. Renewable Energy Research. 2012;2(1).

[14] Ojolo SJ, Abolarin SM, Adegbenro O. Development of a Laboratory Scale Updraft Gasifier. International Journal of Manufacturing Systems. 2012;2(2):21-42.

[15] Mullen CA, Boateng AA, Goldberg NM, Lima IM, Laird DA, Hicks KB. Bio-oil and bio-char production from corn cobs and stover by fast pyrolysis. Biomass and Bioenergy [Internet]. 2010;3 4:67-74. Available from: http://linkinghub.elsevier.com/retrieve/pii/S096195340900203 7
[16] Bulmau C, Marculescu C, Badea A, Apostol T. Pyrolysis Parameters Influencing the Bio-Char Generation from Wooden Biomass. U. P. B. Sci. Bull., Series C. 2010; 72(1):29-38.

[17] tiptoPglobe.com. City (town) Jimma map, population, location [Internet]. 2014. Available from:

http://www.tiptopglobe.com/city?n=Jimma\&p=128330

[18] Okafor IF, Unachukwu GO. Performance Evaluation of Nozzle Type Improved Wood Cook Stove. International Journal of Scientific and Engineering Research. 2013; 4(5):1195-1204.

[19] Komolafe CA, Awogbemi O. Fabrication and Performance Evaluation of an Improved Charcoal Cooking Stove. The Pacific Journal of Science and Technology. 2010;11(2):51-58.

[20] A. D. C, P. S. S, D. NR, D. VS. Design and Development of Household Gasifier cum Water Heater. International Journal of Current Engineering and Technology. 2014; (3):208-212.

[21] Luana Elis de Ramos e Paula, Paulo Fernando Trugilho, Alfredo Napoli, Maria Lúcia Bianchi. CHARACTERIZATION OF RESIDUES FROM PLANT BIOMASS FOR USE IN ENERGYGENERATION. Cerne, Lavras, v. 17, n. 2, p. 237-246, abr./jun. 2011

[22] Panwar NL. Design and performance evaluation of energy efficient biomass gasifier based cookstove on multi fuels. Mitigation and Adaptation Strategies for Global Change [Internet]. 2009;14(7):627-633. Available from: http://link.springer.com/10.1007/s11027-009-9187-4

[23] Cynthia AA, Edwards RD, Johnson M, Zuk M, Rojas L, Jimenez $\mathrm{RD}$, et al. Reduction in personal exposures to particulate matter and carbon monoxide as a result of the installation of a Patsari improved cook stove in Michoacan Mexico. Indoor air [Internet]. 2008; 18(2):93-105. Available from: http://www.ncbi.nlm.nih.gov/pubmed/18333989

[24] Joon V, Kumari H, Chandra A, Bhattacharya M. Predicting Exposure Levels of Respirable Particulate Matter ( PM2. 5 ) and Carbon monoxide for the Cook from Combustion of Cooking Fuels. International Conference on Chemistry and Chemical Process. 2011;10:229-232.

[25] Mukhopadhyay R, Sambandam S, Pillarisetti A, Jack D, Mukhopadhyay K, Balakrishnan K, et al. Cooking practices, air quality, and the acceptability of advanced cookstoves in Haryana, India: an exploratory study to inform large-scale interventions. Global Health Action. 2012;5:1-13.

[26] Chowdhury Z, Le LT, Masud AA, Chang KC, Alauddin M, Hossain M, et al. Quantification of Indoor Air Pollution from Using Cookstoves and Estimation of Its Health Effects on Adult Women in Northwest Bangladesh. Aerosol and Air Quality Research [Internet]. 2012;12:463-475. Available from: http://www.aaqr.org/Doi.php?id=2 AAQR-11-10-OA$0161 \& v=12 \& \mathrm{i}=4 \& \mathrm{~m}=8 \& \mathrm{y}=2012$

[27] Naeher LP, Smith KR, Leaderer BP, Mage D, Grajeda R. Indoor and outdoor PM2.5 and CO in high- and low-density Guatemalan villages. Journal of exposure analysis and environmental epidemiology [Internet]. 2000;10:544-551. Available from: http://www.ncbi.nlm.nih.gov/pubmed/11140438 